\title{
Pengaruh Hemodialisis terhadap Urea Reduction Ratio pada Pasien Penyakit Ginjal Kronik Stadium V di RSUP Dr. M. Djamil Padang
}

\author{
Wahyuni Armezya ${ }^{1}$, Ellyza Nasrul ${ }^{2}$, Elizabet Bahar ${ }^{3}$
}

\begin{abstract}
Abstrak
Pravelensi pasien penyakit ginjal kronik stadium $\mathrm{V}$ yang mendapat terapi hemodialisis terus meningkat di dunia. Dosis hemodialisis yang diberikan kepada pasien harus mencukupi kebutuhan tubuh agar tujuan terapi dapat tercapai dengan baik. Tujuan penelitian ini adalah untuk menentukan pengaruh hemodialisis terhadap Urea Reduction Ratio (URR). Penelitian secara eksperimental kuasi dilakukan pada 55 pasien hemodialisis sejak Agustus 2013 sampai Maret 2014. Data dikumpulkan dari rekam medik dan hasil pemeriksaan ureum sebelum dan sesudah hemodialisis. Analisis bivariat menggunakan uji $\mathrm{t}$ berpasangan dan korelasi Pearson untuk mengetahui perbedaan ureum sebelum dan sesudah hemodialisis serta pengaruh hemodialisis terhadap URR. Berdasarkan data penelitian didapatkan hasil rerata ureum sebelum hemodialisis sebesar 100,27 mg/dl, rerata ureum sesudah hemodialisis 31,17 $\mathrm{mg} / \mathrm{dl}$ dan rerata URR sebesar $68,80 \%$. Sebanyak $62 \%$ pasien mendapatkan hemodialisis yang adekuat dan $38 \%$ pasien mendapatkan hemodialisis tidak adekuat. Uji statistik menunjukkan terdapat perbedaan signifikan ureum sebelum dan sesudah hemodialisis $(p=0,0001)$ dan terdapat pengaruh signifikan hemodialisis terhadap URR $(p=$ $0,0001)$.
\end{abstract}

Kata kunci: hemodialisis, ureum, URR

\section{Abstract}

The prevalence of chronic kidney diseases stage $V$ that receive hemodialysis therapy rise in the world. Hemodialysis doses are given to the patient must meet the body's needs in order to make the therapeutic goals can be achieved well. The objective of this study was to determine the adequacy of hemodialysis measured by URR in hemodialysis patients in the M Djamil hospital Padang. Quasi-experimental studies performed on 55 hemodialysis patients from August 2013 to March 2014. Data were collected from medical records and the results of urea before and after hemodialysis. Bivariate analysis using a paired t test and Pearson correlation urea to know the difference between before and after hemodialysis and hemodialysis influence on the URR. The results showed that the mean of urea levels before hemodialysis is $100.27 \mathrm{mg} / \mathrm{dl}$, the mean of urea levels after hemodialysis is $31.17 \mathrm{mg} / \mathrm{dl}$ and the mean of URR is $68,80 \%$. The $62 \%$ patients got adequate hemodialysis and $32 \%$ patients got inadequate hemodialysis. Based on statistics, obtained $p$ value is 0.0001 showed there are siginificants difference in urea before and after hemodialysis and there are the influence of hemodialysis to URR ( $p$ value: 0.0001 ).

Keywords: hemodialysis, urea, URR

Affiliasi penulis: 1. Pendidikan Dokter FK UNAND (Fakultas Kedokteran Universitas Andalas Padang), 2. Bagian Patologi Klinik FK UNAND, 3. Bagian Mikrobiologi FK UNAND.

Korespondensi: Wahyuni Armezya, email: Armezya135@gmail.com Telp: 08975180141.

\section{PENDAHULUAN}

Penyakit ginjal kronik merupakan suatu keadaan kerusakan ginjal secara bertahap dan progresif karena kehilangan fungsi nefron. Penurunan fungsi ginjal ini bersifat kronis dan ireversibel. ${ }^{1}$ 
Penyakit ginjal kronik stadium $\mathrm{V}$ ditandai dengan penurunan $\mathrm{LFG}<15 \mathrm{ml} /$ menit/1,73m². ${ }^{2}$

Prevalensi dan insidensi penyakit ginjal kronik stadium $\mathrm{V}$ terus meningkat di dunia, termasuk di Indonesia. Hemodialisis sebagai terapi utama pada pasien penyakit ginjal kronik stadium $\mathrm{V}$ harus memperhatikan dosis yang tepat agar sisa-sisa metabolisme seperti ureum dan kreatinin dapat disaring oleh dinding semipermeabel dializer ke luar tubuh. Jika dosis hemodialisis tidak mencukupi maka pasien akan mengalami berbagai gangguan seperti, sakit kepala, kaki kram, mual dan muntah, hipotensi dan pruritus. ${ }^{3}$

Kecukupan dosis hemodialisis diukur dengan istilah adekuasi hemodialisis. Adekuasi hemodialisis secara kuantitatif dapat diukur dengan pemeriksaan Urea Reduction Ratio (URR) yang mengukur persentase jumlah ureum yang dibersihkan dalam sekali tindakan hemodialisis. ${ }^{4}$ Penghitungan URR adalah cara yang paling sederhana dan mudah untuk mengukur adekuasi tindakan hemodialisis. Nilai dari URR sangat tergantung pada aliran cairan dialysate, quick of blood $(Q b)$, jenis dan bahan dializer, pemakaian ulang dializer dan luas permukaan dializer. kecepatan aliran darah, kecepatan aliran dialisat, permeabilitas membran dializer dan resirkulasi. ${ }^{5}$ Nilai URR dalam satu kali tindakan hemodialisis yang direkomendasikan adalah minimal $65 \%{ }^{6}$

Berdasarkan studi pendahuluan yang dilakukan di RS. Dr. M. Djamil, saat ini sejak Januari-September 2013 sudah dilakukan 1452 kali tindakan hemodialisis. Pasien rutin yang melakukan hemodialisis berjumlah 120 orang. Mesin hemodialisis yang digunakan adalah buatan Nipro tipe Surdial+55, akses vaskuler yang digunakan adalah Cimino, quick of blood rata-rata pasien $200-250 \mathrm{ml} /$ menit dan dialisat yang digunakan bikarbonat. Pelaksanaan hemodialisis dilakukan dalam dua shift, yaitu pagi dan sore dengan waktu pelaksanaan hemodialisis rata-rata 5 jam. Pemeriksaan kimia klinik seperti ureum sebelum hemodialisis dilakukan setiap satu kali tiga bulan, namun pemeriksaan kimia klinik sesudah hemodialisis tidak dilakukan sehingga tidak dapat digunakan untuk menghitung URR.

\section{METODE}

Penelitian ini menggunakan metode eksperimental kuasi dilakukan sejak Agustus 2013Maret 2014 di bagian Hemodialisis RS Dr. M. Djamil. Populasi pada penelitian ini berjumlah 120 orang. Sampel yang digunakan sebanyak 55 orang yang memenuhi kriteria inklusi dan eksklusi. Kriteria inklusi adalah semua pasien penyakit ginjal kronik stadium $\mathrm{V}$ yang melakukan hemodialisis rutin 2 (dua) kali seminggu dan bersedia menjadi sampel yang dibuktikan dengan informed consent dan kriteria eksklusi adalah pasien dengan penurunan kesadaran dan anemia berat.

Variabel independen pada penelitian ini adalah hemodialisis dan variabel dependen adalah URR. Pengolahan data yakni checking, coding, entry, dan cleaning data. Data yang diperoleh diolah dalam program komputer dan dianalisis secara univariat dan bivariat. Analisis bivariat menggunakan uji tberpasangan dan korelasi Pearson.

\section{HASIL}

Karakteristik pasien yang menjadi subjek penelitian ditampilkan pada Tabel 1 berikut.

Tabel 1. Karakteristik pasien hemodialisis di RS Dr. M. Djamil

\begin{tabular}{|c|c|c|c|c|}
\hline Variabel & $\mathbf{n}$ & Rerata \pm SD & $\%$ & $\begin{array}{l}\text { Min- } \\
\text { max }\end{array}$ \\
\hline \multicolumn{5}{|l|}{ Jenis kelamin } \\
\hline Laki-laki & 37 & - & 68 & - \\
\hline Perempuan & 18 & - & 32 & - \\
\hline Umur (tahun) & - & $52,18 \pm 11,45$ & - & $\begin{array}{l}14- \\
80\end{array}$ \\
\hline \multicolumn{5}{|l|}{ Lama HD (tahun) } \\
\hline$<1$ tahun & 21 & - & 37,5 & - \\
\hline 1-5 tahun & 23 & - & 41,1 & - \\
\hline$>5$ tahun & 12 & - & 21,4 & - \\
\hline $\begin{array}{l}\text { Batu ginjal } \\
\text { Batu }\end{array}$ & 4 & - & 7,3 & - \\
\hline $\begin{array}{l}\text { ginjal+hipertensi } \\
\text { Glomerulonefritis }\end{array}$ & 1 & - & 1,8 & - \\
\hline kronik & $\begin{array}{l}2 \\
8\end{array}$ & $\begin{array}{l}- \\
-\end{array}$ & $\begin{array}{l}3,6 \\
14,5\end{array}$ & - \\
\hline Nefropati & & & & \\
\hline $\begin{array}{l}\text { DM+Hipertensi } \\
\text { Nefrosklerosis }\end{array}$ & 11 & - & 20 & \\
\hline hipertensi & 21 & - & 38,2 & - \\
\hline Nefropati idiopatik & 6 & - & 10,9 & - \\
\hline Polikistik ginjal & 2 & - & 3,6 & - \\
\hline
\end{tabular}


Subjek penelitian sebanyak 55 orang yang terdiri dari 37 laki-laki (68\%), dan 18 orang perempuan (32\%). Rerata usia pasien secara keseluruhan adalah $52,18 \pm 11,45$ dengan usia termuda adalah 14 tahun dan usia tertua adalah 80 tahun. Tabel 1 menunjukkan lama menjalani hemodialisis terbanyak adalah rentang 1-5 tahun (41,1\%). Berdasarkan data pada Tabel 1 didapatkan etiologi terbanyak adalah nefrosklerosis hipertensi (38,2\%) dan nefropati DM+hipertensi (20\%).

Tabel 2. Kadar ureum serum sebelum dan sesudah hemodialisis

\begin{tabular}{lccc}
\hline \multicolumn{1}{c}{ Variabel } & $\mathbf{n}$ & $\begin{array}{c}\text { Rerata min } \pm \\
\text { SD }\end{array}$ & Min-Max \\
\hline $\begin{array}{l}\text { Ureum } \\
\begin{array}{l}\text { Sebelum HD } \\
\text { (mg/dl) }\end{array}\end{array}$ & 55 & $\begin{array}{l}100,27 \pm \\
27,58\end{array}$ & $45,8-147$ \\
$\begin{array}{l}\text { Ureum } \\
\text { Sesudah HD } \\
\text { (mg/dl) }\end{array}$ & 55 & & $7-71$ \\
& & $31,17 \pm$ & \\
& & 14,43 &
\end{tabular}

Pada Tabel 2 didapatkan hasil rerata ureum sebelum hemodialisis adalah 100, $27 \pm 27,58 \mathrm{mg} / \mathrm{dl}$ dengan kadar ureum sebelum hemodialisis terendah adalah 45, $8 \mathrm{mg} / \mathrm{dl}$ dan kadar ureum tertinggi 147 $\mathrm{mg} / \mathrm{dl}$, rerata kadar ureum sesudah hemodialisis sebesar $31,17 \pm 14,43 \mathrm{mg} / \mathrm{dl}$ dengan kadar ureum sesudah hemodialisis terendah adalah $7 \mathrm{mg} / \mathrm{dl}$ dan kadar ureum tertinggi $71 \mathrm{mg} / \mathrm{dl}$.

Berdasarkan data penelitian pada Tabel 2, kadar ureum sebelum dan sesudah hemodialisis, dihitung URR dengan menggunakan rumus Lowne 1981, yaitu URR (\%) = $100 \times(1-\mathrm{Ct} / \mathrm{Co})$. Nilai minimal URR yang direkomendasikan adalah 65\%, jika URR lebih dari $65 \%$ maka hemodialisis adekuat, sebaliknya jika URR kurang dari $65 \%$ hemodialisis tidak adekuat. ${ }^{6}$

Tabel 3. URR pasien hemodialisis

\begin{tabular}{|c|c|c|c|}
\hline Variabel & $\mathbf{n}$ & Rerata \pm SD & Min-Max \\
\hline & & $68,80 \pm 12,74$ & \\
\hline URR(\%) & 55 & & $31,58-96,57$ \\
\hline
\end{tabular}

Tabel 3 memperlihatkan hasil rerata URR pasien hemodialisis $68,80 \pm 12,74 \%$ dengan URR terendah $31,58 \%$ dan URR tertinggi $96,57 \%$.
Berdasarkan URR yang diperoleh, distribusi pasien yang mendapatkan hemodialisis yang adekuat dan tidak adekuat terdapat pada Tabel 4 berikut.

Tabel 4. Adekuasi hemodialisis berdasarkan URR

\begin{tabular}{lll}
\hline Kategori hemodialisis & $\mathbf{n}$ & $\%$ \\
\hline Adekuat & 34 & 62 \\
\hline Tidak Adekuat & 21 & 38 \\
\hline
\end{tabular}

Berdasarkan data penelitian di atas didapatkan hasil sebanyak 34 orang (62\%) pasien mendapatkan hemodialisis yang adekuat, 21 orang (38\%) pasien mendapatkan hemodialisis yang tidak adekuat.

Analisis bivariat dilakukan untuk melihat besar perbedaan kadar ureum sebelum dan sesudah hemodialisis dengan uji-t berpasangan dan pengaruh hemodialisis terhadap URR. Sebelum melakukan analisis bivariat, terlebih dahulu dilakukan uji normalitas data dengan menggunakan uji nonparametrik Kolmogorov-Smirnov. Hasil uji normalitas data dikatakan normal jika $p>0,05$. Hasil uji normalitas sebagai berikut; ureum sebelum HD $(p=0,56)$, ureum sesudah HD $(p=0,71)$, URR $(p=0,69)$.

Tabel 5. Analisis perbedaan ureum sebelum dan sesudah hemodialisis

\begin{tabular}{cccc}
\hline \multirow{2}{*}{ Variabel } & Rerata \pm SD & \multicolumn{2}{c}{ Analisis } \\
\cline { 3 - 4 } & & Hasil uji & p \\
\hline $\begin{array}{l}\text { Ureum sebelum } \\
\text { dan sesudah HD }\end{array}$ & $71.54 \pm 21,76$ & 0,470 & 0,0001 \\
\hline
\end{tabular}

Pada Tabel 5 diketahui hasil rerata perbedaan ureum sebelum dan sesudah hemodialisis sebesar $71,54 \pm 21,76$. Hasil analisis uji-t berpasangan didapatkan $\mathrm{p}=0,0001$ maka dapat disimpulkan ada perbedaan yang signifikan pada kadar ureum sebelum dan sesudah hemodialisis.

Analisis pengaruh hemodialisis terhadap URR dilakukan dengan uji Korelasi Pearson. Hasil analisis terdapat pada Tabel 6 berikut.

Nilai koefisien korelasi sebesar 0,719. Hal ini menunjukkan bahwa korelasi tersebut positif (menunjukkan hubungan yang searah) yang memiliki 
arti apabila nilai variabel independen (hemodialisis) meningkat maka nilai dari variabel dependen (URR) juga akan meningkat.

Tabel 6. Analisis pengaruh hemodialysis terhadap urea reduction ratio

\begin{tabular}{llll}
\hline Variabel & $\mathbf{n}$ & $\begin{array}{l}\text { Koefisien } \\
\text { Korelasi }\end{array}$ & $\mathbf{p}$ \\
\hline Hemodialisis & 55 & 0,719 & 0,0001 \\
URR & 55 & 1 & 0,0001 \\
\hline
\end{tabular}

Pada analisis korelasi, angka koefisien korelasi 1 menunjukkan adanya korelasi sempurna dan angka koefisien korelasi 0 menunjukkan tidak adanya korelasi. Tidak ada ketentuan yang pasti untuk menentukan seberapa kuat korelasi antar variabel, semakin tinggi nilai koefisien korelasi maka korelasi antar 2 variabel juga semakin tinggi.

\section{PEMBAHASAN}

Penelitian pada pasien hemodialisis di RS Dr. M. Djamil Padang tidak memperhatikan gangguan penyerta pada pasien seperti gagal hati atau malnutrisi, penggunaan dializer berulang, Quick of blood $(\mathrm{Qb})$ dan komponen hemodialisis lainnya.

Subjek penelitian laki-laki lebih banyak dari perempuan.yaitu $68 \%$ dan $32 \%$. Hal ini sejalan dengan penelitian sebelumnya, yaitu didapatkan lakilaki $63,2 \%$ dan $66 \%$. $^{7,8}$

Berdasarkan meta-analisis dari berbagai penelitian pada populasi dengan faktor risiko didapatkan bahwa prevalensi PGK pada perempuan 47 kali lebih tinggi daripada laki-laki. Namun laki-laki berpotensi mengalami penurunan fungsi ginjal secara lebih progresif sehingga sering membutuhkan terapi pengganti ginjal daripada perempuan. Faktor penyebab perbedaan progresifitas penyakit ginjal pada laki-laki dan perempuan masih dalam tahap penelitian, salah satu teori yang berkembang adalah kadar estrogen yang rendah pada laki-laki. Berdasarkan penelitian dengan hewan coba ditemukan bahwa estrogen mengurangi proses pembentukan jaringan ikat (scarring) pada kerusakan ginjal. ${ }^{9}$

Rerata umur responden pada penelitian ini adalah 52,18 tahun. Umur terendah responden adalah
14 tahun dan umur tertinggi adalah 80 tahun. Rerata umur responden di Unit Hemodialisis RS Dr. M. Djamil hampir sama dengan penelitian sebelumnya yaitu didapatkan rerata adalah 51,0 tahun dan 55,1 tahun. ${ }^{7,10}$

Proses penuaan atau bertambahnya umur sesorang akan menurunkan fungsi biologik dari semua organ yang ada. Semakin bertambahnya umur maka akan menambah risiko terjadinya suatu gangguan organ tubuh. ${ }^{11}$

Distribusi lama menjalani hemodialisis terbanyak $(41,4 \%)$ yaitu pada rentang 1-5 tahun. Hal ini sama dengan penelitian sebelumnya yang mendapatkan retata umur adalah 2,3 tahun. Banyaknya pasien yang menjalani hemodialisis dalam rentang waktu 1-5 tahun tersebut kemungkinan karena sarana hemodialisis yang semakin baik sehingga harapan hidup pasien semakin meningkat. ${ }^{12}$

Pada penelitian ini didapatkan penyebab penyakit ginjal kronik tahap akhir (PGK stadium V) adalah nefrosklerosis hipertensi (38,5\%), kemudian disusul nefropati DM+hipertensi (19,6\%). Hal ini hampir sejalan dengan penelitian sebelumnya namun didapatkan perbedaan persentasi yaitu sebanyak 37,5\% DM, hipertensi 20\% dan DM dengan komplikasi 42,3\%. Penelitian lain menunjukkan hasil penelitian yang berbeda yaitu didapatkan etiologi terbanyak adalah batu ginjal sebanyak $30,8 \%$ dan diabetes mellitus $20,5 \%$. $^{13,14}$

Menurut penelitian Iseki et al, pasien penyakit ginjal kronik di Jepang lebih banyak dari lak-laki (mencapai 600 orang per 100.000 penduduk) dibandingkan perempuan (400 orang per 100.000 penduduk). Hal ini terjadi karena perempuan memiliki pola hidup yang lebih sehat dan teratur dibanding lakilaki, misalnya merokok dan minum alcohol. Kebiasaan ini apabila berlangsung lama dapat menimbulkan penyakit hipertensi maupun diabetes mellitus. ${ }^{15}$

Pada data perubahan kadar ureum sebelum dan sesudah hemodialisis pada Tabel 5 terlihat nilai rerata perbedaan antara kadar ureum sebelum dan sesudah hemodialisis adalah 71,54 $\pm 21,76 \mathrm{mg} / \mathrm{dl}$. Hal ini sejalan dengan penelitian sebelumnya didapatkan rerata perbedaan sebesar $74,62 \pm 8,21 \mathrm{mg} / \mathrm{dl}$ namun lebih rendah dari penelitian yang ada, yaitu didapatkan 
perbedaan 100, $90 \pm 39,93 \mathrm{mg} / \mathrm{dl}$. Uji statistik penurunan ureum sebelum dan sesudah hemodialisis juga signifikan. ${ }^{16,11}$

Ureum merupakan zat yang memiliki berat molekul yang rendah, sehingga saat hemodialisis akan mengalami bersihan sekitar 65-70\%. Berat molekul ureum 60 Dalton sehingga saat hemodialisis akan mudah dieliminasi dari aliran darah. ${ }^{17}$

Rerata URR seperti pada Tabel 3 ini lebih tinggi dari penelitian sebelumnya, yaitu didapatkan hasil sebesar $66,3 \% \pm 6,9 \%$ dengan dengan URR terendah adalah $74,7 \%$ dan tertinggi $53,1 \%{ }^{18}$

Nilai URR yang sangat tinggi pada penelitian ini dapat disebabkan oleh kadar ureum yang menurun drastis. Penurunan kadar ureum tersebut dapat diakibatkan oleh faktor gangguan lain pada tubuh pasien, misalnya pada keadaan gagal hati, hidrasi berlebih, keseimbangan nitrogen negatif pada malnutrisi dan malabsorpsi. ${ }^{19}$

\section{KESIMPULAN}

Terdapat penurunan ureum sesudah hemodialisis di RS Dr. M. Djamil Padang.

Terdapat pengaruh signifikan hemodialisis terhadap URR pada pasien hemodialisis di RS. Dr. M. Djamil Padang.

\section{DAFTAR PUSTAKA}

1. Suwitra K. Penyakit ginjal kronis. Dalam: Sudoyo AW, Setiyohadi B, Alwi I, Simadibrata KM, Setiati $\mathrm{S}$, editor (penyunting). Buku Ajar IImu Penyakit dalam. Edisi ke-5. Jakarta: FKUI; 2009. hlm.103540.

2. KDIGO. Clinical practice guideline for the evaluation and management of chronic kidney disease. Kid Int 2013;1(Suppl 3):18-27.

3. Locatelli F, Buoristiani, Canaud, Kohler, Petitclerc, Zucchelli. Dialysis dose and frequency. Nephrology Dialysis Transplantation. 2005;20:285-96.

4. NKF-K/DOQI. Clinical practice guideline for hemodialysis adequacy. 2006 (diunduh 21 Oktober 2013).Tersedia dari:URL: HYPERLINK http:// www. kidney.org/kidneydisease/CKD/indse.cfm\#what

5. Zyga S, Sarafis P. Haemodialysis adequacy. Health Science Journal. 2009; 3(suppl 4):209-13.
6. Persatuan Nefrologi Indonesia (PERNEFRI). Konsensus Dialisis Pernefri: Jakarta; 2003.

7. Dewi IG. Hubungan antara quick of blood $(\mathrm{Qb})$ dengan adekuasi hemodialisis pada pasien yang menjalani hemodialisis di ruang HD BRSU Daerah Tabanan Bali (tesis). Jakarta: Universitas Indonesia; 2010.

8. Erwinsyah. Hubungan antara quick of blood $(\mathrm{Qb})$ dengan penurunan kadar ureum dan kreatinin pada pasien CKD yang menjalani hemodialisa di RSUD Mattaher Jambi (tesis). Jakarta: Universitas Indonesia; 2009.

9. Zhang Qiu-Li, Rothen Bacher D. Prevalence of chronic kidney disease in population based studies: systematic review. BMC Public Health. 2008 (diunduh 12 Desember 2013). Tersedia dari: URL: HYPERLINK http://www.biomedcentral.com/ $1471-2458 / 8 / 117$

10. Naysilla AM. Faktor risiko hipertensi intradialitik pasien penyakit ginjal kronik di RS. Kariadi Semarang (skripsi). Semarang: Fakultas Kedokteran Universitas Diponegoro; 2012.

11. Fowler B. Functional and biological markers of aging. Dalam: Klatz, R, author (penulis). Anti-Aging Medical Therapeutics. Vol ke-5. Chicago: The A4M Publications; 2003. hlm.43.

12. Nugraha A. Korelasi perubahan tekanan darah pra dan pasca dialisis dengan lama menjalani hemodialisis pada pasien hemodialisis kronik di RSUPN Cipto Mangunkusumo pada bulan Februari 2009 (skripsi). Jakarta: Fakultas Kedokteran Universitas Indonesia; 2009.

13. Pranoto I. Hubungan antara lama hemodialisis dengan terjadinya perdarahan intraserebral (skripsi). Surakarta: Fakultas Kedokteran Universitas Sebelas Maret; 2010.

14. Oktiadewi AA, Ayu Putri. Hubungan kadar Hb dan status gizi dengan kualitas hidup pasien penyakit ginjal kronik stadium $V$ yang menjalani hemodialisis. (undergraduated thesis). Semarang: Fakultas Kedokteran Universitas Diponegoro; 2012.

15. Iseki K. Gender differences in chronic kidney disease. Kidney International. 2008;74:415-17.

16. Kaliahpan P. Perubahan kadar ureum dan kreatinin 
sebelum dan sesudah hemodialisis pada penderita gagal ginjal di RSUD Pirngadi Medan (skripsi). Medan: Fakultas Kedokteran Universitas Sumatera Utara; 2010.

17. Paston S, Balley J. Dialysis theraphy. The New England Journal of Medicine.1998;338(20):142837.

18. Yuwono, Hadi I, Arniyati, Yunie, Chanif. Pengaturan kecepatan aliran darah (quick of blood). terhadap rasio reduksi ureum pada pasien penyakit ginjal kronik yang menjalani hemodialisis di Unit Hemodialisis RSUD Kota Semarang. (undergraduate tesis). Semarang: Universitas Muhammadiyah Semarang; 2013.

19. Pagana KD, Pagana TJ. Mosby's manual of diagnostic and laboratory tests. Edisi ke-2. St Louis; Mosby's; 2002. 